Original research article

Food Quality and Functionality Section

\title{
Sensory Assessment and Physicochemical Properties of Wheat Bread Supplemented with Chia Seeds
}

\author{
Stanistaw Kowalski ${ }^{1 *}$ (๑), Anna Mikulec ${ }^{2}{ }^{\circledR}$, Henryk Pustkowiak ${ }^{3}$ \\ ${ }^{1}$ Department of Carbohydrate Technology, Faculty of Food Technology, University of Agriculture in Krakow, \\ ul. Balicka 122, 30-149 Krakow, Poland \\ ${ }^{2}$ State University of Applied Sciences in Nowy Sacz, ul. Staszica 1, 33-300 Nowy Sacz, Poland \\ ${ }^{3}$ Department of Cattle Breeding, Faculty of Animal Science, University of Agriculture in Krakow, \\ Al. Mickiewicza 24/28, 31-120 Krakow, Poland
}

Key words: wheat-chia bread, sensory profile, fatty acid profile, consumer acceptability test

Quantitative descriptive analysis, consumer acceptability as well as physicochemical characteristics were employed to analyse the effect of ground chia seeds on the texture and quality of wheat bread. Chia seed oil changes and its impact on selected characteristics were determined. The share of chia seeds did not contribute to bread quality deterioration. The addition of $7.5 \%$ chia seeds significantly reduced consumer acceptance as well as contributed to the development of undesirable features in the sensory profile, including fatty, rancid, and off-flavour. The share of chia seeds in an amount not exceeding 5\% did not deteriorate the overall quality of bread. The composition of fatty acids of bread with chia seeds, especially with their 5 and $7.5 \%$ addition, could be valuable from the nutritional point of view. The fatty acid profile of bread with 5 and $7.5 \%$ chia seeds was characterised by over $50 \%$ higher polyunsaturated fatty acids to saturated fatty acids ratio compared to wheat bread. The $n-6 / n-3$ ratio in the fatty acid profile of wheat bread was 18.77, while in the fatty acid profile of chia seed bread it ranged from 1.42 to 0.67 . Oil extracted from bread exhibited better quality features as compared to oil extracted from chia seeds and subjected to the oil oxidative stability test.

\section{INTRODUCTION}

Chia (Salvia hispanica L.), a plant that belongs to the Lamiaceae family, has been known for many centuries. Due to nutritional and health effects, chia seeds become more and more popular in many countries, especially across the Europe. Nowadays, they have found various applications, such as functional food, animal feed, and cosmetics [Dinçoğlu \& Yeşildemir, 2019]. Some studies have shown their consumption to yield beneficial effects on such health problems as insulin resistance, dyslipidemia, cardiovascular diseases, or inflammation [Vuksan et al., 2017]. In recent years, consumers expect food with additional health benefits resulting from its consumption. They seek for a healthy lifestyle, which is also associated with the growing food awareness.

In 1997, the European Parliament approved chia seeds as a novel food, which resulted in its increased use in food production. Consumption of chia seeds is not typical in the European culture, but bread is still a staple food product in the diet of many people. The addition of chia seeds to popular food products, including bread, can be a perfect dietary supplement and bring a number of health benefits for consumers. Additives used for food supplementation can, on the one

\footnotetext{
* Corresponding Author: Tel.: +48 126624781;

E-mail: rrkowals@cyf-kr.edu.pl (S. Kowalski)
}

hand, improve the nutritional value of bread, but on the other hand, contribute to its diminished sensory acceptance.

Chia seeds, due to their chemical composition, have a high nutritional potential. They contain protein of a high biological value with such essential amino acids as isoleucine, leucine, lysine, and valine. For this reason, chia seeds can be a supplement of cereal proteins that are deficient in essential amino acids, especially lysine. In addition, the seeds contain fatty acids, and in particular are a valuable source of $n-3$ and $n-6$ fatty acids [Sandoval-Oliveros \& Paredes-Lopez, 2013; Vázquez-Ovando et al., 2010]. Due to the high content of fatty acids, including unsaturated ones, product with seeds of chia may be susceptible to rancid processes, which may lead to lowered consumer acceptance. Chia seeds are characterised by a high dietary fibre content, mainly the water soluble fraction [Vázquez-Ovando et al., 2010], and are an important source of natural antioxidants [Reyes-Caudillo et al., 2008]. They can be a valuable supplement in conventional therapy for overweight and obesity in diabetics because of the glycaemic control and a high dietary fibre content [Vuksan et al., 2017]. Mohd Ali et al. [2012] concluded that chia oil can maintain a balanced serum lipid profile, while Citelli et al. [2016] observed changes in the lipid profile in the liver caused by chia oil supplementation. Chia inter alia has been used for the production of bread [Coelho \& Salas-Mellado, 2015; Hrušková \& Švec, 2015; Miranda-Ramos et al., 2020; Romankiewicz et al., 2017], pasta [Oliveira et al., 2015], and even ice cream 
[Campos et al., 2016]. Several studies of bread with chia seeds showed that they contributed to the technological quality and texture parameters, depending on additive type - flour or seeds, and the method of their preparation. For example, Coelho \& Salas-Mellado [2015] observed a decrease in the specific volume and the total score values, and an increase in the firmness of bread crumbs with chia seeds. In turn, Romankiewicz et al. [2017] noticed that the addition of chia seeds decreased baking losses, but also bread volume and crumb hardness, whereas Hrušková \& Švec [2015] determined higher elasticity of dough containing hydrated chia resulting in firmer crumb compared to the bread with dry chia flour. All listed authors concluded that the addition of chia seeds increased the nutritional value of the bread, for example bread with chia contained more dietary fibre and mineral components. Products with chia seeds were characterised by a rich fatty acid composition and a higher content of phenolic compounds. Miranda-Ramos et al. [2020] pointed out that phytates of chia seeds may affect the bioavailability of such microelements like $\mathrm{Zn}$ and Fe. They also emphasised that the glycaemic index was lower in bread with chia ingredients compared to wheat bread, which in combination with nutritional benefits could be clinically important for the prevention of metabolic diseases. In sensory evaluation, the breads with chia seeds met with consumer acceptance. Romankiewicz et al. [2017] concluded that the substitution of wheat flour with chia seeds up to 6\% did not negatively affect the final product acceptance.

Due to the composition of chia seeds, it was hypothesised that although their addition can improve the nutritional value of the bread, it may, on the other hand, contribute to a decreased consumer acceptance resulting from oxidative changes of fats. However, there is a lack of data regarding the influence of chia seeds on the oxidative stability of fats contained in the products with their addition. In this study, ground chia seeds were added to the dough, which can contribute to the better utilization of nutrients but also could result in faster oxidation changes of fats during bread baking. It should be emphasised that most of the studies on the nutritional, technological, and sensory value of bakery and pastry products are carried out with seeds or grains, defatted or refined flour. Considering that the intestinal transit time in humans is too short to digest whole seeds and grains, it seems important to supplement bread with crushed seeds or grains. In the present study, wheat flour was partially replaced with ground chia seeds, thanks to which the bread was enriched with all the valuable nutrients contained in the whole grain, which offers both technological, nutritional, and sensorial novelty. For this reason, the aim of this study was to evaluate the effect of substituting some part of wheat flour with ground chia seeds on selected physicochemical and textural properties, on the technological and sensory quality, as well as on the acceptance of bread with $2.5,5$, or $7.5 \%$ of ground chia seeds.

\section{MATERIALS AND METHODS}

\section{Materials}

Formulation and bread making method by Mikulec et al. [2019] was applied. Some part of wheat flour (WF) type 650 (PZZ Stoislaw, Poland) was replaced with ground chia seeds (Natura Food, Intenson Europe sp. z o. o., Poland) in the fol- lowing wheat/chia ratios $(w / w)$ : 97.5/2.5 (WCh2.5); 95/5 (WCh5) and 92.5/7.5 (WCh7.5). The chia seeds were ground using a laboratory mill (KM13, Bosch, Gerlingen, Germany). Standard wheat bread (WS) was also prepared. Forty loaves were prepared for each sample from two batches.

\section{Chemicals used in the experiment}

The following chemicals were used for analyses: petroleum ether, chloroform, acetic acid glacial, potassium iodide, sodium thiosulfate, starch soluble phenolphthalein, sodium hydroxide, potassium hydroxide, sodium chloride, $n$-hexane, methyl orange, ethanol, sodium methylate (Avantor Performance Materials S.A., Gliwice, Poland), 12\% boron trifluoride, Supelco 37 component FAME Mix and CLA isomers, MES hydrate, TRIZMA $®$ base (Sigma-Aldrich Co., St. Louis, MO, USA), sulphuric acid, acetone (PPH Stanlab, Sp. z o.o., Lublin, Poland), Kjeltabs (Foss, Hillerød, Denmark), hydrochloric acid (PPUH Tarchem Sp. z o.o., Tarnowskie Góry, Poland), Tashiro indicator, boric acid, (Chempur, Piekary Śląskie, Poland), buffer solutions $\mathrm{pH} 4.0,7.0$, and 9.0 (Eurochem BGD. Sp. z o.o., Tarnów, Poland), and total dietary fibre assay kit (Megazyme, Bray, Ireland).

\section{Analysis of the proximate composition of wheat flour and chia seeds}

The contents of water (AOAC 925.10), protein (AOAC 950.36), crude fat (AOAC 935.38), starch (AOAC 996.11), ash (AOAC 923.03), total, and soluble and insoluble dietary fibre (AOAC 991.43) were determined following the Association of Official Analytical Chemists (AOAC) methods [AOAC, 2006]. Analyses was performed in duplicate. Results were expressed as $\mathrm{g} / 100 \mathrm{~g}$ dry matter (d.m.).

\section{Analysis of the basic quality features of bread}

Two hours after baking, some instrumental quality parameters of bread, such as bread volume [AACC, 2000], total baking loss [Majzoobi et al., 2011], and crumb moisture (AOAC 925.10) [AOAC, 2006] were determined.

\section{Texture analysis}

Selected texture parameters of the bread crumb, such as hardness, cohesiveness, chewiness, gumminess, springiness, and resilience, were determined acording to the procedure described by Szcześniak [2002]. Cylindrical samples of crumb $(\mathrm{r}=40 \mathrm{~mm}, \mathrm{~h}=30 \mathrm{~mm})$ were analysed with a TA.XT2.Plus texture analyzer (Stable Micro System, Surrey, UK) equipped with $5 \mathrm{~kg}$ load cell, using an aluminium, cylinder probe $(\varphi=36 \mathrm{~mm})$, at the test speed of $2 \mathrm{~mm} / \mathrm{s}$, deformation of the entire sample height reaching $75 \%$, and pause of $10 \mathrm{~s}$. Measurements were done in ten replications.

\section{Consumer acceptability}

Consumer acceptability tests using a 9-point hedonic scale [Stone \& Sidel, 2004] were performed by a panel consisting of 75 untrained potential consumers (20-60 years old, 49 females and 26 males) who were habitual consumers of bread. Consumers were recruited from different institutes of the State Higher Vocational School in Nowy Sacz, Poland (staff and students). 


\section{Sensory profile}

The assessment was carried out in a sensory laboratory at the State University of Applied Sciences in Nowy Sacz, Poland, which meets the requirements of the Internatioanl Organization for Standarization (ISO) 8589 standard [ISO, 2010]. Descriptive sensory profiling of breads using a quantitative descriptive analysis (QDA), according to ISO 13299 standard [ISO, 2016] was carried out $4 \mathrm{~h}$ after baking by a panel of 8 assessors (in two independent repetitions) ( $\mathrm{n}=8,7$ women and 1 man, aged from 21 to 49), qualified as experts - according to ISO 8586 standard [ISO, 2014] and having appropriate methodological (theoretical and practical) preparation in the field of sensory methods and extensive experience in conducting assessments using quantitative descriptive analysis. Bread samples (35 g, a thickness of $12 \pm 2 \mathrm{~mm}$ ) were placed on previously prepared and coded disposable paper trays. Pure water having a temperature of $20^{\circ} \mathrm{C}$ was used as a taste neutralizer between samples. Samples were presented to the assessors simultaneously.

The attributes of the analysed products were selected in accordance with the ISO 13299 procedure [ISO, 2016] and their definitions were established. Twenty qualitative attributes were selected and defined (Table 1). The 100-mm unstructured linear scale with marked boundary values from 0 to 10 conventional units (c.u.), where 0 meant no intensity of a given attribute, and 10 meant high intensity of a given attribute, was used. Results were calculated using Microsoft Excel 10.0 software (Microsoft, Redmond, WA, USA).

\section{Analysis of oil extracted from bread and chia seeds}

Chia seeds as well as bread supplemented with 7.5\% chia seeds (WCh7.5) were analysed for oil fraction stability. The WCh7.5 sample was selected from among breads, due to the highest content of fat and possibly the greatest effect on the oxidative changes in fat. For this purpose, chia seeds/ bread samples were milled using a laboratory mill (KM13, Bosch Germany), and the oil was extracted with petroleum ether $(1: 3, w / v)$ for $3 \mathrm{~h}$ with continuous stirring. After decanting, fresh petroleum ether was added to the solid residue, and the extraction procedure was repeated twice. After collection, all liquid phases were centrifuged and the supernatant was removed from the oil fraction by evaporation using a vacuum evaporator (RV 10 C S99, IKA, Königswinter, Germany).

The oils obtained were subjected to the following analyses:

\section{Oil oxidative stability test}

Chia oil extracted from chia seeds/bread was subjected to the oxidation stability test according to Pike [2001]. The analysis kit consisted of a purified compressed air cylinder with a flow regulator, and a thermostat. The air used for the measurement was drawn through the filter and the water vapour was removed by means of a molecular sieve. Oil sample was thermostated at $60^{\circ} \mathrm{C}$ under a constant air flow $(20 \mathrm{~L} / \mathrm{h})$ and continuously aerated for 5 days. The samples were then analysed for peroxide and iodine values as well as free fatty acid content.
TABLE 1. Sensory attributes of breads used in the quantitative descriptive analysis (QDA).

\begin{tabular}{|c|c|c|}
\hline Attribute & Definition & $\begin{array}{l}\text { Word anchors } \\
(0-10 \text { c.u. })\end{array}$ \\
\hline \multicolumn{3}{|c|}{ Appearance } \\
\hline $\begin{array}{l}\text { Beige colour } \\
\text { of the crust }\end{array}$ & $\begin{array}{l}\text { Visual perception of the bread } \\
\text { crust colour }\end{array}$ & light $\rightarrow$ dark \\
\hline Porosity & $\begin{array}{l}\text { Visual perception of the bread } \\
\text { crumb porosity/porous }\end{array}$ & $\begin{array}{l}\text { poreless } \rightarrow \\
\text { porous }\end{array}$ \\
\hline \multicolumn{3}{|c|}{ Odour } \\
\hline Flour & Odour typical of flour & $\begin{array}{l}\text { none } \rightarrow \text { very } \\
\text { intensive }\end{array}$ \\
\hline Grain-seed & $\begin{array}{l}\text { Odour typical of cereal } \\
\text { grains, dried seeds, bran }\end{array}$ & $\begin{array}{l}\text { none } \rightarrow \text { very } \\
\text { intensive }\end{array}$ \\
\hline Alcoholic & $\begin{array}{l}\text { Odour typical of the ethyl } \\
\text { alcohol (ethanol) }\end{array}$ & $\begin{array}{l}\text { none } \rightarrow \text { very } \\
\text { intensive }\end{array}$ \\
\hline Buttery & Odour typical of butter & $\begin{array}{l}\text { none } \rightarrow \text { very } \\
\text { intensive }\end{array}$ \\
\hline Rancid & Odour typical of rancid oil & $\begin{array}{l}\text { none } \rightarrow \text { very } \\
\text { intensive }\end{array}$ \\
\hline Fatty & Odour typical of fat & $\begin{array}{l}\text { none } \rightarrow \text { very } \\
\text { intensive }\end{array}$ \\
\hline Off-odour & $\begin{array}{l}\text { Smell of something other than } \\
\text { "regular" smell of bread }\end{array}$ & $\begin{array}{l}\text { none } \rightarrow \text { very } \\
\text { intensive }\end{array}$ \\
\hline \multicolumn{3}{|c|}{ Flavour } \\
\hline Sweet & $\begin{array}{l}\text { Taste characteristic to sugar } \\
\text { or substance containing or } \\
\text { resembling sugar, as honey or } \\
\text { saccharin (basic taste illustrated } \\
\text { by sucrose diluted in water } 1.5 \% \text { ) }\end{array}$ & $\begin{array}{l}\text { none } \rightarrow \text { very } \\
\text { intensive }\end{array}$ \\
\hline Bitter & $\begin{array}{c}\text { The taste experience when quinine } \\
\text { or coffee is taken into the mouth } \\
\text { (basic taste illustrated by caffeine } \\
\text { diluted in water, } 0.5 \% \text { ) }\end{array}$ & $\begin{array}{l}\text { none } \rightarrow \text { very } \\
\text { intensive }\end{array}$ \\
\hline Grain-seed & $\begin{array}{l}\text { Taste characteristic to cereal } \\
\text { grains, dried seeds, bran }\end{array}$ & $\begin{array}{l}\text { none } \rightarrow \text { very } \\
\text { intensive }\end{array}$ \\
\hline Acidulous & The intensity of the acidulous taste & $\begin{array}{l}\text { none } \rightarrow \text { very } \\
\text { intensive }\end{array}$ \\
\hline Rancid & Taste typical of rancid oil & $\begin{array}{l}\text { none } \rightarrow \text { very } \\
\text { intensive }\end{array}$ \\
\hline Fatty & Taste typical of fat & $\begin{array}{l}\text { none } \rightarrow \text { very } \\
\text { intensive }\end{array}$ \\
\hline Off-flavour & $\begin{array}{l}\text { Taste of something other than } \\
\text { "regular" flavour of the bread }\end{array}$ & $\begin{array}{l}\text { none } \rightarrow \text { very } \\
\text { intensive }\end{array}$ \\
\hline \multicolumn{3}{|c|}{ Texture (mouth feel) } \\
\hline Hardness & $\begin{array}{l}\text { The force required to } \\
\text { bite bread samples }\end{array}$ & $\begin{array}{l}\text { not hard } \\
\rightarrow \text { hard }\end{array}$ \\
\hline Chewiness & $\begin{array}{l}\text { The energy required to chew } \\
\text { a product until it is ready to } \\
\text { be swallowed (the number } \\
\text { of chews used to prepare } \\
\text { the product to be swallowed) }\end{array}$ & $\begin{array}{l}\text { not chewy } \\
\rightarrow \text { chewy }\end{array}$ \\
\hline Adhesiveness & $\begin{array}{l}\text { The force required to } \\
\text { remove bread crumbs }\end{array}$ & low $\rightarrow$ high \\
\hline Moistness & Slightly or moderately wet & dry $\rightarrow$ moist \\
\hline
\end{tabular}

\section{Peroxide value determination}

The analysis was done according to the 3960 ISO standard [ISO, 2017]. The peroxide value was expressed in mmol of active oxygen per kilogram of the sample. As a result, the mean of two parallel determinations was assumed. 
Free fatty acid determination

Free fatty acid (FFA) content was determined according to Del Flores-Álvarez et al. [2012] procedure. The results were expressed as lauric acid equivalents. The assay was carried out in duplicate for each sample. FFA content was calculated as follows (Eq. 1):

$\% \mathrm{FFA}$ as lauric acid $=$

$=\frac{\mathrm{mL} \mathrm{NaOH} \times \mathrm{NaOH} \text { molarity } \times 20 \text { (equivalent weights) }}{\text { weight }(\mathrm{g})}$

\section{Iodine value determination}

The test was made according to the European Committee for Standardization (CEN) DIN EN 14111 standard [CEN, 2003]. The iodine value was expressed as grams of $I_{2}$ absorbed by $100 \mathrm{~g}$ of the sample. As a result, the mean of two parallel determinations was assumed.

\section{Determination of fatty acid profile}

The extraction of total lipids was performed in duplicate according to the Folch et al. [1957] method, while the derivatisation and determination of total fatty acid composition were performed according to the AOAC - approved method 991.39 [AOAC, 2006]. Briefly, to the fat extracted (10 mg), $0.5 \mathrm{~mL}$ of $0.5 \mathrm{~N} \mathrm{KOH}$ (methanol solution) was added and heated to $85^{\circ} \mathrm{C}$, then $1 \mathrm{~mL}$ of $12 \% \mathrm{BF}_{3}$ (methanol solution) was added, and the mixture was reheated at $85^{\circ} \mathrm{C}$. After cooling to room temperature, $1 \mathrm{~mL}$ of hexane and $5 \mathrm{~mL}$ of saturated $\mathrm{NaCl}$ solution were added. About $1 \mu \mathrm{L}$ of the resulting sample was injected onto the column connected to the TRACE GC ULTRA chromatograph (Thermo Electron Corporation, Milano, Italy) with a flame ionization detector (FID). Operating parameters were as follows: FID temperature $250^{\circ} \mathrm{C}$; dispenser temperature $220^{\circ} \mathrm{C}$; oven temperature $160^{\circ} \mathrm{C}(3 \mathrm{~min})$ to $210^{\circ} \mathrm{C}\left(3^{\circ} \mathrm{C} / \mathrm{min}\right)\left(210^{\circ} \mathrm{C}, 35 \mathrm{~min}\right)$. SUPELCOWAX 10 column ( $30 \mathrm{~m}, 0.25 \mathrm{~mm}, 0.25 \mu \mathrm{m}$ ) was used and helium was applied as a carrier gas at a flow rate of $1 \mathrm{~mL} / \mathrm{min}$. Split flow was $10 \mathrm{~mL} / \mathrm{min}$. Individual fatty acid methyl esters were identified by comparison to the standards of a mixture of Supelco 37 component FAME Mix, and of CLA isomers.

\section{Nutritional properties}

Nutritional properties of lipids were evaluated using three indexes: the atherogenicity index (AI), the ratio of hypocholesterolemic to hypercholesterolemic fatty acids $(\mathrm{HH})$, and the thrombogenicity index (TI) (Eq. 2-4) [Ulbricht \& Southgate, 1991]:

$$
\begin{aligned}
& \mathrm{AI}=\frac{\mathrm{C} 12: 0+[4 \times \mathrm{C} 14: 0]+\mathrm{C} 16: 0}{\sum \mathrm{MUFA}+\sum(\mathrm{n}-6)+\sum(\mathrm{n}-3)} \\
& \mathrm{HH}=\frac{\mathrm{C} 18: 1 n 9+\mathrm{C} 18: 2+\mathrm{C} 20: 4+\mathrm{C} 18: 3+\mathrm{C} 20: 5+\mathrm{C} 22: 5+\mathrm{C} 22: 6}{\mathrm{C} 14: 0+\mathrm{C} 16: 0} \\
& \mathrm{TI}=\frac{\mathrm{C} 14: 0+\mathrm{C} 16: 0+\mathrm{C} 18: 0}{0.5 \cdot \mathrm{C} 18: 1+0.5(\operatorname{MUFA}-\mathrm{C} 18: 1)+0.5 \times \operatorname{PUFA}(n-6)+3} \\
& \times \operatorname{PUFA}(n-3)+\frac{\operatorname{PUFA}(n-3)}{\operatorname{PUFA}(n-6)}
\end{aligned}
$$

where: MUFA - monounsaturated fatty acids, PUFA - polyunsaturated fatty acids.

\section{Statistical analysis}

The analysis of variance (ANOVA) and Duncan posthoc test $(\mathrm{p}<0.05)$ as well as principal component analysis (PCA) were performed using Statistica 13.3 (Stat Soft, Kraków, Poland).

\section{RESULTS AND DISCUSSION}

\section{Analysis of the basic quality features of wheat flour and chia seeds}

The wheat flour and chia seeds used for bread making differed significantly $(\mathrm{p}<0.05)$ in the content of proximate chemical components. In comparison with the wheat flour, chia seeds had approx. 1.5 times higher protein content, approx. 22 times higher crude fat content, approx. 10 times higher total dietary fibre content, and approx. 8 times higher mineral components content, which confirms their high nutritional value (Table 2). The chemical composition of chia seeds used in the present study is similar to that reported by other authors [Coelho \& Salas-Mellado, 2015; Hrušková et al., 2015]. Therefore, substituting a part of wheat flour with ground chia seeds had to contribute to the increase in the nutritional value of the bread.

\section{Analysis of the basic quality features of bread}

The bread with chia seeds did not differ significantly in the total baking loss, which ranged from $14.25 \%$ for wheat bread to $14.75 \%$ for bread with $2.5 \%$ chia seeds (Table 3 ). No influence of chia seeds on bread volume was observed, which ranged from $883.25 \mathrm{~mL}$ for bread with $7.5 \%$ chia seeds to $897.67 \mathrm{~mL}$ for wheat bread. A decrease in crumb moisture was observed in the bread with chia seeds addition, on the day of baking (Table 3). Opposite results were obtained by Romankiewicz et al. [2017], who observed an increase in the baking loss after chia seeds addition and a reduction in bread volume, compared to wheat bread. However, Hrušková et al. [2015] obtained a larger volume of bread with chia flour,

\begin{tabular}{|c|c|c|c|}
\hline & & Chia seeds & Wheat flour \\
\hline \multicolumn{2}{|c|}{ Moisture (g/100 g) } & $6.87 \pm 0.06^{\mathrm{b}}$ & $13.73 \pm 0.06^{\mathrm{a}}$ \\
\hline \multicolumn{2}{|c|}{ Protein (g/100 g d.m.) } & $20.58 \pm 0.01^{\mathrm{a}}$ & $14.12 \pm 0.03^{b}$ \\
\hline \multicolumn{2}{|c|}{ Crude fat (g/100 g d.m.) } & $33.99 \pm 0.01^{\mathrm{a}}$ & $1.56 \pm 0.01^{\mathrm{b}}$ \\
\hline \multirow{3}{*}{$\begin{array}{l}\text { Dietary fibre } \\
\text { (g/100 g d.m.) }\end{array}$} & Soluble & $3.45 \pm 0.04^{\mathrm{a}}$ & $1.61 \pm 0.01^{\mathrm{b}}$ \\
\hline & Insoluble & $25.81 \pm 0.05^{\mathrm{a}}$ & $1.36 \pm 0.04^{\mathrm{b}}$ \\
\hline & Total & $29.25 \pm 0.01^{\mathrm{a}}$ & $2.97 \pm 0.04^{b}$ \\
\hline \multicolumn{2}{|c|}{ Ash (g/100 g d.m.) } & $4.96 \pm 0.01^{\mathrm{a}}$ & $0.65 \pm 0.00^{\mathrm{b}}$ \\
\hline \multicolumn{2}{|c|}{ Starch (g/100 g d.m.) } & $0.00 \pm 0.00^{\mathrm{a}}$ & $73.13 \pm 0.01^{\mathrm{b}}$ \\
\hline
\end{tabular}
which was caused by the initial hydration of chia flour due to water absorption by chia polysaccharides. It is well known

TABLE 2. Chemical composition of chia seeds and wheat flour.

Values (mean \pm standard deviation) in the same row marked with different letters are significantly different at $\mathrm{p}<0.05$; d.m. - dry matter. 
that free water evaporates quicker during baking and storage, compared to the bound one. Despite the reduction of the gluten protein in bread, a larger loaf volume was obtained as a result of the addition of a gluten-free raw material, such as chia flour. Bread volume depends on the type and amount of protein used in dough formulation, as well as on its interaction with starch. Although chia seeds have a high protein content, it cannot form a continuous gluten-like network, thus impairing water entrapment. Additionally, proteins compete with starch for water, delaying starch swelling and gelatinization [Gnanavinthan et al., 2010]. Therefore, in reference to our research and that of other authors, it can be concluded that the method of bread dough preparation, especially involving raw gluten-free and high-fibre content, can be very important for loaf volume, baking loss, or bread crumb moisture content.

\section{Texture analysis}

The hardness of the bread crumb is one of the most important and often determined parameters in bread texture studies. It is the main determinant of bread quality and is closely related to the perception of bread as fresh to consumers. The highest hardness on the day of baking was determined in the breads with 2.5 and $5 \%$ share of chia seeds, reaching 3.10 and $3.25 \mathrm{~N}$, respectively (Table 3 ). There was no significant difference between the hardness of the wheat bread and bread with the $7.5 \%$ chia seed content. An increase in cohesiveness, gumminess, and chewiness of bread crumbs with chia seeds was observed, compared to wheat bread. A positive effect of 5 and $7.5 \%$ of chia seeds on the reduction of gumminess and chewiness of crumb was observed in comparison to other breads (Table 3). The changes in the texture of the bread crumb were mainly due to the decreased gluten content caused by the addition of chia seeds, an ingredient with a higher dietary fibere and fat content [Collar et al., 2007]. Bread dough is a complex system in which the interaction between the different ingredients may cause various effects. Depending on their amount, the additives used in bread making can change textural properties, for example fat restricts starch swelling during baking. During baking, anti-firming components interact with wheat flour starch molecules and decrease starch swelling. As a result, less surface area is exposed to gluten and weaker cross-linking with protein occurs; therefore, the firming rate is reduced [Scheuer et al., 2016]. For resilience, a significant increase $(p<0.05)$ was observed in the bread with $7.5 \%$ share of chia seeds (Table 3). Coelho \& Salas-Mellado [2015] obtained similar results; they observed an increase in the firmness of bread crumbs with chia on the baking day. Meanwhile, Romankiewicz et al. [2017] reported a 4 to $8 \%$ decrease in the crumb hardness, gumminess, and chewiness of bread with chia addition on the baking day, compared to the standard one. Comparing the texture profile assessed by the sensory panel to the results obtained from

TABLE 3. Characteristics of wheat bread and breads with addition of chia seeds.

\begin{tabular}{|c|c|c|c|c|}
\hline Bread type & WS & WCh2.5 & WCh5 & WCh7.5 \\
\hline \multicolumn{5}{|c|}{ Physicochemical parameters } \\
\hline Total baking loss (\%) & $14.25 \pm 0.55^{\mathrm{a}}$ & $14.75 \pm 0.60^{\mathrm{a}}$ & $14.28 \pm 0.60^{\mathrm{a}}$ & $14.60 \pm 0.46^{\mathrm{a}}$ \\
\hline Volume (mL) & $898 \pm 13^{\mathrm{a}}$ & $892 \pm 12^{\mathrm{a}}$ & $885 \pm 10^{\mathrm{a}}$ & $883 \pm 10^{\mathrm{a}}$ \\
\hline Moisture of bread crumb (g/100 g) & $45.70 \pm 0.01^{\mathrm{a}}$ & $45.28 \pm 0.09^{\mathrm{b}}$ & $45.17 \pm 0.13^{b}$ & $45.30 \pm 0.08^{\mathrm{b}}$ \\
\hline \multicolumn{5}{|c|}{ Texture parameters } \\
\hline Hardness (N) & $2.74 \pm 0.12^{\mathrm{b}}$ & $3.10 \pm 0.13^{\mathrm{a}}$ & $3.25 \pm 0.12^{\mathrm{a}}$ & $2.79 \pm 0.12^{\mathrm{ab}}$ \\
\hline Springiness (-) & $0.94 \pm 0.03^{\mathrm{ab}}$ & $0.89 \pm 0.01^{\mathrm{b}}$ & $0.89 \pm 0.04^{\mathrm{b}}$ & $0.96 \pm 0.02^{\mathrm{a}}$ \\
\hline Cohesiveness (-) & $0.66 \pm 0.03^{\mathrm{d}}$ & $0.81 \pm 0.01^{\mathrm{b}}$ & $0.78 \pm 0.02^{\mathrm{c}}$ & $0.85 \pm 0.02^{\mathrm{a}}$ \\
\hline Gumminess (N) & $2.12 \pm 0.09^{c}$ & $3.54 \pm 0.07^{\mathrm{a}}$ & $2.49 \pm 0.16^{\mathrm{b}}$ & $2.52 \pm 0.09^{\mathrm{b}}$ \\
\hline Chewiness $(\mathrm{N} \cdot \mathrm{mm})$ & $1.96 \pm 0.09^{c}$ & $3.34 \pm 0.13^{\mathrm{a}}$ & $2.69 \pm 0.14^{b}$ & $2.84 \pm 0.17^{\mathrm{b}}$ \\
\hline Resilience (-) & $0.40 \pm 0.01^{\mathrm{b}}$ & $0.40 \pm 0.02^{\mathrm{b}}$ & $0.41 \pm 0.01^{\mathrm{b}}$ & $0.51 \pm 0.01^{\mathrm{a}}$ \\
\hline \multicolumn{5}{|c|}{ Consumer acceptability } \\
\hline Taste & $8.9 \pm 0.30^{\mathrm{a}}$ & $8.8 \pm 0.47^{\mathrm{a}}$ & $8.3 \pm 0.48^{\mathrm{b}}$ & $7.5 \pm 0.45^{\mathrm{c}}$ \\
\hline Texture & $8.9 \pm 0.30^{\mathrm{a}}$ & $8.8 \pm 0.40^{\mathrm{a}}$ & $8.2 \pm 0.31^{\mathrm{b}}$ & $7.6 \pm 0.32^{\mathrm{c}}$ \\
\hline Aroma & $8.7 \pm 0.47^{\mathrm{a}}$ & $8.6 \pm 0.50^{\mathrm{a}}$ & $8.4 \pm 0.68^{b}$ & $7.6 \pm 0.65^{\mathrm{c}}$ \\
\hline Crumb colour & $8.8 \pm 0.40^{\mathrm{a}}$ & $8.7 \pm 0.67^{a}$ & $8.1 \pm 0.53^{\mathrm{b}}$ & $7.1 \pm 0.48^{c}$ \\
\hline Crust colour & $8.8 \pm 0.42^{a}$ & $8.7 \pm 0.51^{\mathrm{a}}$ & $8.0 \pm 0.42^{\mathrm{b}}$ & $7.2 \pm 0.67^{c}$ \\
\hline Overall acceptability & $8.9 \pm 0.30^{\mathrm{a}}$ & $8.8 \pm 0.52^{a}$ & $8.2 \pm 0.45^{b}$ & $7.3 \pm 0.42^{\mathrm{c}}$ \\
\hline
\end{tabular}

WS - wheat bread, WCh2.5 - bread with $2.5 \%$ addition of chia seeds, WCh 5 - bread with 5\% addition of chia seeds, WCh 7.5 - bread with $7.5 \%$ addition of chia seeds. Values (mean \pm standard deviation) in the same row marked with different letters are significantly different at $\mathrm{p}<0.05$. 
instrumental tests, the evaluators did not evaluate the hardness of WCh7.5 at a similar level as for wheat bread (Table 4). It may be due to the fact that only crumb hardness was analysed using a texturometer, in comparison to whole bread slices in the QDA.

\section{Consumer acceptability}

Consumer preference assessments provide very important and valuable information for food and drink producers, however they are not sufficient. Food producers should meet the expectations and needs of consumers, because without consumer acceptance they will not achieve the intended success. A new product should meet the certain level of quality required by the consumers because only a few percent of new products are fitted on the market.

In the consumer acceptance test, wheat bread and bread with $2.5 \%$ of chia seeds obtained similar scores (Table 3 ) and did not differ significantly $(\mathrm{p} \geq 0.05)$. Other breads differed $(p<0.05)$ by means of the organoleptic evaluation compared to WS and WCh2.5, as well as differed among each other. The lowest scores were given to the bread with a $7.5 \%$ share of chia seeds. This bread obtained much lower scores, especially for the colour of crumb and crust and overall acceptability, which ranged from 7.1 to 7.3 (Table 3).

Other authors observed deterioration in the organoleptic characteristics, lower rating and consumer acceptance of bread with chia seeds [Coelho \& Salas-Mellado, 2015; Hrušková et al., 2015]. Hrušková et al. [2015] observed lower scores given for the appearance, texture, and overall acceptability to the bread with $8 \%$ addition of chia seeds. Deterioration of the organoleptic properties of bread enriched with such non-cereal additives like hemp [Mikulec et al., 2019], cistus extract [Mikulec et al., 2020], herbs [Adams et al., 2011], and others can be explained by the content of essential oils that cause its specific taste and smell. The same explanation can be applied to the changes observed in the present study.

\section{Descriptive sensory profiling}

The manufacturer must know not only how product is rated by consumers, but also why it has received a specific rating. Sensory profile analysis provides valuable answers to the "why" question. The method of sensory profiling (QDA) assumes that sensory characteristics are not homogeneous, but consist of a number of individual distinguishing attributes, a significant part of which can be identified and separately analysed.

In the sensory profile of the obtained breads, the flour and alcoholic odours were significantly less perceptible in the breads with $5 \%$ share of chia seeds, but significantly more grain-seed odour and flavour were detected in all breads with chia seeds (Table 4), compared to wheat bread. The share of chia seed contributed to the appearance of fatty flavour as well as rancid and off-flavour, mainly in WCh7.5 (Table 4). Regarding the textural properties, the assessors did not observe the difference between chia seed breads and wheat bread.

The PCA analysis allows finding dependencies in a data set, better data representation, classification, pattern searching, or dimension reduction. Values are not evenly distributed along all directions of the multidimensional coordinate sys-
TABLE 4. Intensity of the sensory attributes of breads.

\begin{tabular}{|c|c|c|c|c|}
\hline Attribute & WS & WCh2.5 & WCh5 & WCh7.5 \\
\hline Crust colour & $3.0 \pm 0.5^{\mathrm{c}}$ & $3.2 \pm 0.5^{\mathrm{c}}$ & $4.5 \pm 0.7^{b}$ & $7.5 \pm 0.2^{\mathrm{a}}$ \\
\hline Porosity & $9.5 \pm 1.6^{\mathrm{a}}$ & $9.2 \pm 0.9^{\mathrm{a}}$ & $8.6 \pm 1.9^{a}$ & $8.4 \pm 2.2^{\mathrm{a}}$ \\
\hline Flour (odour) & $3.1 \pm 0.4^{\mathrm{a}}$ & $2.8 \pm 0.6^{\mathrm{a}}$ & $1.1 \pm 0.3^{\mathrm{b}}$ & $0.9 \pm 0.3^{b}$ \\
\hline Grain-seed (odour) & $0.6 \pm 0.5^{\mathrm{d}}$ & $2.1 \pm 0.5^{\mathrm{c}}$ & $3.9 \pm 0.5^{b}$ & $5.5 \pm 0.9^{a}$ \\
\hline Alcoholic (odour) & $3.6 \pm 1.0^{\mathrm{a}}$ & $2.3 \pm 0.8^{\mathrm{a}}$ & $1.4 \pm 0.5^{b}$ & $1.3 \pm 0.3^{\mathrm{b}}$ \\
\hline Buttery (odour) & $0.5 \pm 0.0^{\mathrm{a}}$ & $0.0 \pm 0.0^{\mathrm{b}}$ & $0.0 \pm 0.0^{\mathrm{b}}$ & $0.0 \pm 0.0^{\mathrm{b}}$ \\
\hline Rancid (odour) & $0.0 \pm 0.0^{\mathrm{b}}$ & $0.0 \pm 0.0^{\mathrm{b}}$ & $0.0 \pm 0.0^{\mathrm{b}}$ & $1.5 \pm 0.5^{\mathrm{a}}$ \\
\hline Fatty (odour) & $0.0 \pm 0.0^{\mathrm{d}}$ & $0.9 \pm 0.2^{\mathrm{c}}$ & $1.5 \pm 0.5^{b}$ & $2.5 \pm 0.5^{\mathrm{a}}$ \\
\hline Off-odour & $0.0 \pm 0.0^{\mathrm{b}}$ & $0.0 \pm 0.0^{\mathrm{b}}$ & $0.0 \pm 0.0^{\mathrm{b}}$ & $1.5 \pm 0.5^{\mathrm{a}}$ \\
\hline Sweet & $0.0 \pm 0.0^{\mathrm{a}}$ & $0.0 \pm 0.0^{\mathrm{a}}$ & $0.0 \pm 0.0^{\mathrm{a}}$ & $0.0 \pm 0.0^{\mathrm{a}}$ \\
\hline Bitter & $0.0 \pm 0.0^{\mathrm{a}}$ & $0.0 \pm 0.0^{\mathrm{a}}$ & $0.0 \pm 0.0^{\mathrm{a}}$ & $0.0 \pm 0.0^{\mathrm{a}}$ \\
\hline Grain-seed (flavour) & $0.6 \pm 0.2^{\mathrm{d}}$ & $3.5 \pm 0.5^{c}$ & $5.3 \pm 1.1^{\mathrm{b}}$ & $6.6 \pm 1.9^{\mathrm{a}}$ \\
\hline Acidulous & $0.0 \pm 0.0^{\mathrm{a}}$ & $0.0 \pm 0.0^{\mathrm{a}}$ & $0.0 \pm 0.0^{\mathrm{a}}$ & $0.0 \pm 0.0^{\mathrm{a}}$ \\
\hline Rancid (flavour) & $0.0 \pm 0.0^{\mathrm{b}}$ & $0.0 \pm 0.0^{\mathrm{b}}$ & $1.6 \pm 0.5^{\mathrm{a}}$ & $2.5 \pm 1.5^{\mathrm{a}}$ \\
\hline Fatty (flavour) & $0.0 \pm 0.0^{\mathrm{d}}$ & $1.5 \pm 0.6^{\mathrm{c}}$ & $2.50+0.9^{\mathrm{b}}$ & $4.5 \pm 1.5^{\mathrm{a}}$ \\
\hline Off-flavour & $0.0 \pm 0.0^{\mathrm{b}}$ & $0.0 \pm 0.0^{\mathrm{b}}$ & $0.0 \pm 0.0^{\mathrm{b}}$ & $2.1 \pm 0.9^{\mathrm{a}}$ \\
\hline Hardness & $3.6 \pm 1.5^{\mathrm{a}}$ & $4.1 \pm 2.2^{\mathrm{a}}$ & $4.3 \pm 1.9^{\mathrm{a}}$ & $5.4 \pm 2.3^{\mathrm{a}}$ \\
\hline Chewiness & $4.5 \pm 1.8^{\mathrm{a}}$ & $5.1 \pm 2.5^{\mathrm{a}}$ & $4.8 \pm 1.0^{\mathrm{a}}$ & $5.2 \pm 0.9^{a}$ \\
\hline Adhesiveness & $8.6 \pm 1.2^{\mathrm{a}}$ & $8.2 \pm 0.9^{\mathrm{a}}$ & $7.8 \pm 0.5^{\mathrm{a}}$ & $7.4 \pm 0.8^{a}$ \\
\hline Moistness & $5.6 \pm 0.5^{a}$ & $6.1 \pm 0.7^{\mathrm{a}}$ & $5.8 \pm 0.9^{a}$ & $4.9 \pm 1.1^{\mathrm{a}}$ \\
\hline
\end{tabular}

WS - wheat bread, WCh2.5 - bread with $2.5 \%$ addition of chia seeds, WCh 5 - bread with $5 \%$ addition of chia seeds, WCh7.5 - bread with $7.5 \%$ addition of chia seeds. Values (mean \pm standard deviation) in the same row marked with different letters are significantly different at $\mathrm{p}<0.05$.

tem, but show concentrations in certain subspaces. Finding these subspaces allows seeing patterns that are invisible or unnoticeable in the original data layout. The PCA transformation determines the correlation that occurs between multiple variables in a data set. If the data are correlated, then knowing only some of them is enough to determine the characteristics of the tested product [Jolliffe \& Cadima, 2016].

The PCA of textural and sensory data of the analysed breads shows that principal component 1 and principal component 2 described $91.42 \%$ of the total variation. The PCA plots (Figure 1a and 1b) indicate that standard wheat bread (WS) was closely related to porosity, alcoholic odour, and adhesiveness. WCh2.5 bread was well correlated with moisture content, hardness, and gumminess (both parameters from instrumental texture analysis). WCh7.5 bread was related to such sensory attributes like crust colour, grain-seed, rancid and off-odour, rancid and off-flavour, and with such instrumental texture parameters like springiness and resilience. In turn, WCh5 bread showed a poor correlation with the attributes correlated with the first principal component but correlated with grain-seed, and off-odour, grain-seed, and fatty taste as well as with hardness from sensory assessment. 
TABLE 5. Quality characteristics of chia oil during oxidative stability test.

\begin{tabular}{lcc|c|c}
\hline Sample & Time (day) & $\begin{array}{c}\text { Iodine value } \\
\left(\mathrm{g} \mathrm{I}_{2} / 100 \mathrm{~g}\right)\end{array}$ & $\begin{array}{c}\text { Peroxide value } \\
\left(\mathrm{mmol} \mathrm{O}_{2} / \mathrm{kg}\right)\end{array}$ & $\begin{array}{c}\text { Free fatty acid content } \\
(\mathrm{mg} \mathrm{NaOH} / \mathrm{g})\end{array}$ \\
\hline Oil extracted from bread WCh7.5 (OFB) & 0 & $86.12 \pm 0.39^{\mathrm{a}}$ & $22.51 \pm 0.49^{\mathrm{b}}$ & $3.41 \pm 0.15^{\mathrm{c}}$ \\
& 5 & $86.66 \pm 0.59^{\mathrm{a}}$ & $37.93 \pm 0.84^{\mathrm{a}}$ & $6.24 \pm 0.04^{\mathrm{b}}$ \\
Oil extracted from chia seed (OCS) & 0 & $85.70 \pm 0.79^{\mathrm{a}}$ & $5.04 \pm 0.17^{\mathrm{c}}$ & $0.85 \pm 0.1^{\mathrm{d}}$ \\
& 5 & $88.73 \pm 2.99^{\mathrm{a}}$ & $37.74 \pm 0.22^{\mathrm{a}}$ & $8.79 \pm 0.03^{\mathrm{a}}$ \\
\hline
\end{tabular}

WCh7.5 - bread with $7.5 \%$ addition of chia seeds. Values (mean \pm standard deviation) in the same columns marked with different letters are significantly different at $\mathrm{p}<0.05$.

\section{Analysis of bread and chia oil oxidative stability}

During storage, fat may undergo some changes as a result of hydrolysis, oxidation, and polymerization processes, which lead to undesirable organoleptic and chemical changes, lowering the nutritional value as well as consumer acceptance. Such changes can also result in the formation of compounds harmful to health. Especially changes among the fat fraction result in undesired sensory deterioration. There are many factors influencing the oil stability, like fatty acid composition, presence of thermally-oxidised compounds, oxidative enzymes, and antioxidants [Manzocco et al., 2016].

According to the Codex Alimentarius [Joint WHO/ FAO Codex Alimentarius Commission, 2017] requirements, in cold-pressed oils, the content of free fatty acids resulting from fat hydrolysis should be $\leq 4.0 \mathrm{mg} \mathrm{KOH} / \mathrm{g}$ and the peroxide value should be at $<15 \mathrm{mmol} / / \mathrm{kg}$. Oil samples from chia seed (OCS) and from bread with $7.5 \%$ of chia seeds (OFB), extracted on the baking day, met the requirements specified in the Codex Alimentarius [Joint WHO/FAO Codex Alimentarius Commission, 2017] for the free fatty acid content (Table 5). After five days of storage, the FFA content of OFB increased to $6.24 \mathrm{mg} \mathrm{KOH} / \mathrm{g}$ (almost dou- ble) and in OCS to $8.79 \mathrm{mg} \mathrm{KOH} / \mathrm{g}$ (more than 10 -fold). The peroxide value of OCS did not exceed the allowable level on the first day of the oxidation stability test. The peroxide value of OFB was higher compared to OCS, which may be due to the thermal processes that take place in bread during baking. Qualitative changes in OCS after five days of aerating at $60^{\circ} \mathrm{C}$ corresponded to the changes that took place in OFB. The iodine value, which is a measure of the degree of unsaturation of fats used to identify them in products, did not change during bread storage, compared to the value obtained on the bread baking day. For OCS, it changed slightly from 85.70 to $88.73 \mathrm{~g} \mathrm{I}_{2} / 100 \mathrm{~g}$ (Table 5) and the increase observed was statistically insignificant $(p \geq 0.05)$. The obtained results indicate that in breads after 5 day of storage, the process of chia seeds fat oxidation was less advanced as compared to pure chia seeds oil extracted from raw material and subjected to the oil oxidative stability test. The high value of the iodine value indicates a high content of unsaturated fatty acids in the tested samples, which was confirmed by the fatty acid profile. Similar observations were made by Maire et al. [2013] who investigated baked products enriched with raw materials, being the source of unsaturated a)

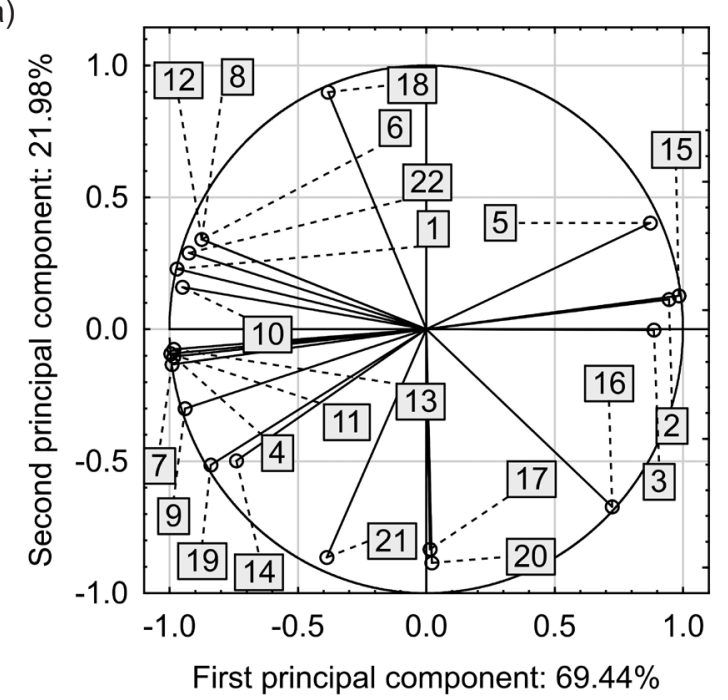

b)

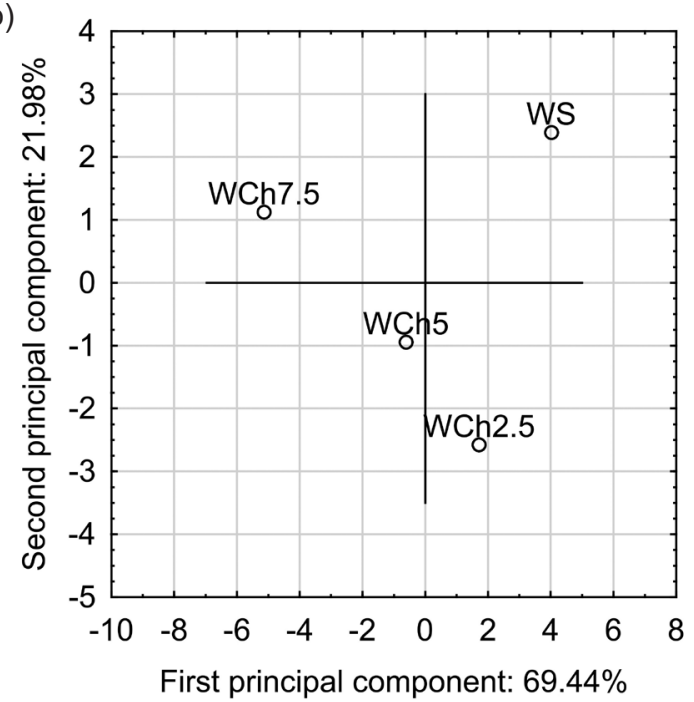

FIGURE 1. a) Projection of variables on the factor plane x: Crust colour (1), Porosity (2), Flour (3), Grain-seed (odour) (4), Alcoholic (odour) (5), Rancid (odour) (6), Fatty (odour) (7), Off-odour (8), Grain-seed (taste) (9), Rancid (taste) (10), Fatty (taste) (11), Off-flavour (taste) (12), Hardness (13), Chewiness (14), Adhesiveness (15), Moistness (16), Hardness txt (17), Springiness txt (18), Cohesiveness txt (19), Gumminess txt (20), Chewiness txt (21), Resilience txt (22); b) Projection of cases on the factor plane x: WS - wheat bread, WCh2.5 - bread with 2.5\% of chia seeds, WCh5 - bread with $5 \%$ of chia seeds, WCh7.5 - bread with $7.5 \%$ of chia seeds. 
TABLE 6. Fatty acid profile and fat nutritional quality of chia seeds and supplemented breads.

\begin{tabular}{|c|c|c|c|c|c|}
\hline Fatty acids & Chia seeds & WS & WCh2.5 & WCh5 & WCh7.5 \\
\hline \multicolumn{6}{|c|}{ Content ( $\%$ of total fatty acids) } \\
\hline 12:0 & $0.004 \pm 0.001^{\mathrm{d}}$ & $0.028 \pm 0.003^{\mathrm{a}}$ & $0.011 \pm 0.000^{\mathrm{b}}$ & $0.007 \pm 0.000^{c}$ & $0.007 \pm 0.000^{c}$ \\
\hline 14:0 & $0.027 \pm 0.004^{\mathrm{d}}$ & $0.233 \pm 0.009^{\mathrm{a}}$ & $0.101 \pm 0.002^{\mathrm{b}}$ & $0.076 \pm 0.000^{c}$ & $0.071 \pm 0.005^{\mathrm{c}}$ \\
\hline 15:0 & $0.013 \pm 0.001^{\mathrm{e}}$ & $0.212 \pm 0.004^{\mathrm{a}}$ & $0.089 \pm 0.000^{\mathrm{b}}$ & $0.078 \pm 0.001^{\mathrm{c}}$ & $0.052 \pm 0.000^{\mathrm{d}}$ \\
\hline 16:0 & $6.178 \pm 0.092^{\mathrm{e}}$ & $20.636 \pm 0.201^{\mathrm{a}}$ & $16.308 \pm 0.219^{\mathrm{b}}$ & $14.625 \pm 0.541^{\mathrm{c}}$ & $13.341 \pm 0.476^{\mathrm{d}}$ \\
\hline $16: 1 n-9$ & $0.046 \pm 0.007^{\mathrm{e}}$ & $0.560 \pm 0.0040^{\mathrm{a}}$ & $0.199 \pm 0.019^{b}$ & $0.141 \pm 0.011^{\mathrm{c}}$ & $0.098 \pm 0.003^{\mathrm{d}}$ \\
\hline $16: 1 n-7$ & $0.062 \pm 0.004^{\mathrm{e}}$ & $0.298 \pm 0.004^{\mathrm{a}}$ & $0.221 \pm 0.002^{\mathrm{b}}$ & $0.149 \pm 0.009^{c}$ & $0.119 \pm 0.006^{\mathrm{d}}$ \\
\hline 17:0 & $0.028 \pm 0.000^{\mathrm{e}}$ & $0.091 \pm 0.004^{\mathrm{b}}$ & $0.072 \pm 0.001^{\mathrm{c}}$ & $0.103 \pm 0.000^{\mathrm{a}}$ & $0.063 \pm 0.000^{\mathrm{d}}$ \\
\hline $17: 1$ & $0.011 \pm 0.001^{\mathrm{d}}$ & $0.042 \pm 0.006^{\mathrm{a}}$ & $0.034 \pm 0.000^{\mathrm{b}}$ & $0.027 \pm 0.003^{\mathrm{c}}$ & $0.022 \pm 0.009^{c}$ \\
\hline 18:0 & $2.178 \pm 0.095^{\mathrm{c}}$ & $0.801 \pm 0.021^{\mathrm{d}}$ & $2.161 \pm 0.012^{\mathrm{c}}$ & $3.166 \pm 0.065^{\mathrm{b}}$ & $3.376 \pm 0.035^{\mathrm{a}}$ \\
\hline $18: 1 n-9$ & $4.699 \pm 0.057^{\mathrm{e}}$ & $9.380 \pm 0.047^{\mathrm{a}}$ & $7.405 \pm 0.057^{\mathrm{b}}$ & $6.998 \pm 0.052^{\mathrm{c}}$ & $6.513 \pm 0.133^{\mathrm{d}}$ \\
\hline $18: 1 n-7$ & $0.623 \pm 0.033^{\mathrm{d}}$ & $0.817 \pm 0.044^{\mathrm{a}}$ & $0.724 \pm 0.006^{c}$ & $0.619 \pm 0.012^{\mathrm{d}}$ & $0.741 \pm 0.005^{\mathrm{b}}$ \\
\hline $18: 2 n-6$ & $18.658 \pm 0.062^{\mathrm{e}}$ & $63.155 \pm 0.181^{\mathrm{a}}$ & $42.421 \pm 0.139^{\mathrm{b}}$ & $30.724 \pm 0.401^{\mathrm{c}}$ & $30.072 \pm 0.028^{\mathrm{d}}$ \\
\hline $18: 3 n-3$ & $67.216 \pm 0.085^{\mathrm{a}}$ & $3.365 \pm 0.042^{\mathrm{e}}$ & $29.876 \pm 0.025^{\mathrm{d}}$ & $42.813 \pm 0.136^{c}$ & $45.097 \pm 0.263^{b}$ \\
\hline 20:0 & $0.172 \pm 0.004^{\mathrm{d}}$ & $0.078 \pm 0.013^{\mathrm{e}}$ & $0.180 \pm 0.001^{\mathrm{c}}$ & $0.318 \pm 0.009^{\mathrm{a}}$ & $0.277 \pm 0.003^{\mathrm{b}}$ \\
\hline 20:1 & $0.088 \pm 0.000^{\mathrm{d}}$ & $0.308 \pm 0.008^{\mathrm{a}}$ & $0.200 \pm 0.008^{\mathrm{b}}$ & $0.160 \pm 0.009^{c}$ & $0.155 \pm 0.005^{\mathrm{c}}$ \\
\hline \multicolumn{6}{|c|}{ Nutritional indexes of fat } \\
\hline$\Sigma$ SFA & 8.600 & 22.079 & 18.922 & 18.373 & 17.187 \\
\hline$\Sigma$ MUFA & 5.529 & 11.405 & 8.783 & 8.094 & 7.648 \\
\hline$\Sigma$ PUFA & 85.874 & 66.520 & 72.297 & 73.537 & 75.169 \\
\hline AI & 0.06 & 0.28 & 0.21 & 0.18 & 0.17 \\
\hline TI & 0.04 & 0.46 & 0.16 & 0.12 & 0.11 \\
\hline $\mathrm{HH}$ & 14.6 & 3.64 & 4.86 & 5.48 & 6.09 \\
\hline PUFA/SFA & 9.98 & 3.01 & 3.82 & 4.00 & 4.37 \\
\hline$n-6 / n-3$ & 0.28 & 18.77 & 1.42 & 0.72 & 0.67 \\
\hline
\end{tabular}

SFA - saturated fatty acids; MUFA - monounsaturated fatty acids; PUFA - polyunsaturated fatty acids; AI - atherogenicity index; HH - ratio of hypocholesterolemic to hypercholesterolemic fatty acids, TI - thrombogenicity index; WS - wheat bread, WCh2.5 - bread with $2.5 \%$ addition of chia seeds, WCh 5 - bread with $5 \%$ addition of chia seeds, WCh7.5 - bread with $7.5 \%$ addition of chia seeds. Values (mean \pm standard deviation) in the same row marked with different letters are significantly different at $\mathrm{p}<0.05$.

fats, and observed that lipid oxidation occurred at a very early stage (during dough preparation) and to a minor extent during the baking process.

\section{Determination of fatty acid profile}

Chia seed oil can be an alternative for vegetarians and people who are allergic to fish products [Zettel \& Hitzmann, 2018]. PUFA $n-6$ and $n-3$ are essential fatty acids that must be derived from the diet. The human body does not have a suitable enzyme for the endogenic synthesis of $\alpha$-linolenic and linoleic acid, due to the lack of desaturases introducing double bonds at the $3^{\text {rd }}$ and $6^{\text {th }}$ carbon atoms in the carbon chain. These acids are precursors for the synthesis of long-chain polyene fatty acids such as eicosapentaenoic acid and docosahexaenoic acid [Martynowicz et al., 2019].
In the fatty acid profile of chia seeds as well as bread supplemented with chia seeds, predominant were the 18-carbon chain fatty acids, with their contents reaching up to $82.42 \%$ in WCh7.5 and 93.37 in chia seeds (Table 6).

$\alpha$-Linolenic acid (18:3n-3) had the greatest share in the fatty acid profile of chia seeds and the lowest one in the fatty acid profile of wheat bread (67.216 and 3.365\%, respectively). Analyses showed a significant increase in the share of $18: 3 n-3$ in the fatty acid profile of breads along with chia seed content increase from 29.876 in WCh2.5 to $45.097 \%$ in WCh7.5, and a significant decrease in the share of linoleic acid (18:2n-6) in the fatty acid profile of breads with increasing chia seed content. In the fatty acid profile of wheat bread, a much greater share of 18:2n-6 was observed compared to the profiles of other breads (Table 6). Osuna et al. [2016] and Melilli et al. 
[2020] observed similar proportions in the fatty acid profile of wheat bread.

Chia oil is a valuable source of $\alpha$-linolenic acid and phytosterols. The nutritional value of bread with chia seeds was evaluated by such nutritional indexes as AI, HH, TI, PUFA/ SFA, and the $n-6 / n-3$ ratio. These indexes evaluate the nutritional quality of foods based on their fatty acid compositions. $\mathrm{AI}$ and TI can be used as predictors or risk factors for cardiovascular diseases and should be kept at low levels in a healthy everyday diet [Ulbricht \& Southgate, 1991]. The AI ranged from 0.17 for WCh7.5 to 0.28 for WS, meanwhile for chia seeds it reached 0.06. A decrease in the value of this index was observed along with an increase in chia seed content in bread. The TI ranged from 0.11 to 0.46 for WCh7.5 and wheat bread, respectively, and was 0.04 for chia seeds. The HH index indicates the effect of fatty acids on cholesterol metabolism and its high value is important from a nutritional point of view. The HH values ranged from 3.64 for WS to 6.09 for WCh7.5 (14.6 for chia seeds). An increase in the value of this index was observed with the increase in chia seed content in bread. Another increase was observed in the breads with chia seeds for the PUFA/SFA ratio. Its values ranged from 3.01 (WS) to 4.37 (WCh7.5), while for chia seeds it was 9.98 (Table 6). A low PUFA/SFA ratio in diets is considered a risk factor for increased blood cholesterol levels. In the present study, the PUFA/SFA ratio determined for the breads with chia seeds was by 0.8 to 1.4 times higher than that determined for wheat bread. Due to a high content of linolenic acid in chia seeds, their addition to bread formulations caused a significant decrease in the $n-6 / n-3$ ratio which ranged from 1.42 (WCh2.5) to 0.67 (WCh7.5). While, for wheat bread, its value was as high as 18.77 . Modern western diets provide excessive levels of $n-6$ but very low levels of $n-3$ fatty acids, leading to an undesired (from a nutritional point of view) $n-6 / n-3$ ratio, characterised by 10 - to 20 -fold predominance of $n-6$ acids [Simopoulos, 2008]. Therefore, the ratio of 18:3n-3 to 18:2n-6 in chia seeds and hence bread supplemented with this seeds may have beneficial effects on the human health [Smith et al., 2011]. Other authors observed similar relationships regarding the improvement of the nutritional value of bread upon the addition of functional ingredients, like purslane flour [Melilli et al., 2020] or oilseeds, such as flax or soybeans [Osuna et al., 2016]. Therefore, consuming the bread with chia seeds would help increase the $n-3$ intake in the dietary habits of the population. Overall, the nutritional indexes used for quality evaluation indicated that breads with chia seeds, especially with their $5 \%$ and $7.5 \%$ content, could have beneficial health effects for consumers.

\section{CONCLUSION}

The wheat grain and chia seeds used for bread making differed significantly in the content of proximate chemical components. The addition of chia seeds to dough formulations at the three levels tested did not deteriorate bread quality. The total baking loss and loaf volume of the breads with chia seed addition did not differ significantly from these of the wheat bread. The sensory and organoleptic quality of food products is considered to be the key fac- tor driving consumers' purchase decisions. The chia seed content not exceeding 5\% did not contribute to reducing the overall sensory quality of bread. The addition of $7.5 \%$ chia seeds significantly reduced consumer acceptance due to the appearance of fatty, rancid, and off-flavour. The chemical composition of chia seeds, especially the composition of fatty acids, is very valuable from the nutritional point of view. Enrichment and fortification of bakery products with chia seeds could be justified for nutritional reasons. The results do not confirm the negative impact of chia seeds on shortening the bread shelf life resulting from oxidative changes of fats.

\section{RESEARCH FUNDING}

This research was financed by the Ministry of Science and Higher Education of the Republic of Poland from founds for year 2020 .

\section{CONFLICT OF INTEREST}

Authors declare no conflict of interest.

\section{ORCID IDs}

S. Kowalski https://orcid.org/0000-0001-5269-0291 A. Mikulec https://orcid.org/0000-0002-2737-5967

\section{REFERENCES}

1. AACC. (2000). Approved Methods of the AACC (10th ed.). St Paul, MN: USA: American Association of Cereal Chemists.

2. Adams, A., Kruma, Z., Verhé, R., De Kimpe, N., Kreicbergs, V. (2011). Volatile profiles of rapeseed oil flavored with basil, oregano, and thyme as a function of flavoring conditions. Journal of the American Oil Chemists' Society, 88(2), 201-212. https://doi.org/10.1007/s11746-010-1661-3

3. AOAC. (2006). Official Methods of Analysis (18th ed.). Gainthersburg, MD: AOAC - Association of Analytical Chemists International.

4. Campos, B., Ruivo, T., Scapim, M., Madrona, G., Bergamasco, R. (2016). Optimization of the mucilage extraction process from chia seeds and application in ice cream as a stabilizer and emulsifier. LWT - Food Science and Technology, 65, 874-883.

https://doi.org/10.1016/j.Iwt.2015.09.021

5. Citelli, M., Fonte-Faria, T., Vargas-Silva, S., Barja-Fidalgo, C. (2016). Dietary supplementation with chia (Salvia hispanica L.) oil reduces the complications caused by high fat diet-induced obesity. The FASEB Journal, 30(1 Supplement), 907-920.

6. Coelho, M.S., Salas-Mellado, M. (2015). Effects of substituting chia (Salvia hispanica L.) flour or seeds for wheat flour on the quality of the bread. LWT - Food Science and Technology, 60(2), 729-736.

https://doi.org/10.1016/j.Iwt.2014.10.033

7. Collar, C., Santos, E., Rosell, C.M. (2007). Assessment of the rheological profile of fibre-enriched bread doughs by response surface methodology. Journal of Food Engineering, 78(3), 820-826.

https://doi.org/10.1016/j.jfoodeng.2005.11.026 
8. Del Flores-Álvarez, C., Molina-Hernández, E.F., Hernández-Raya, J.C., Sosa-Morales, M.E. (2012). The effect of food type (fish nuggets or french fries) on oil blend degradation during repeated frying. Journal of Food Science, 77(11), C1136-C1143. https://doi.org/10.1111/j.1750-3841.2012.02930.x

9. Dinçoğlu, A.H., Yeşildemir, Ö. (2019). A renewable source as a functional food: chia seed. Current Nutrition \& Food Science, 15(4), 327-337.

https://doi.org/10.2174/1573401314666180410142609

10. European Committee for Standardization. (2003). Fat and oil derivatives - Fatty acid methylesters (FAME) - Determination of iodine value (DIN EN standard No.14111).

11. Folch, J., Lees, M., Sloane-Stanley, G.H. (1957). A simple method for the isolation and purification of total lipids from animal tissues. Journal of Biological Chemistry, 226, 497-509.

12. Gnanavinthan, A., Sun-Waterhouse, D., Quek, S., Perera, C. (2010). Properties of bread dough with added fiber polysaccharides and phenolic antioxidants: a review. Journal of Food Science, 75(8), R163-R174.

https://doi.org/10.1111/j.1750-3841.2010.01815.x

13. Hrušková, M., Švec, I. (2015). Chemical, rheological and bread characteristics of wheat flour influenced by different forms of chia (Salvia hispanica L.). Emirates Journal of Food and Agriculture, 27(12), 872-877.

https://doi.org/10.9755/ejfa.2015-04-073

14. Internatioanl Organization for Standarization. (2017). Animal and vegetable fats and oils - Determination of peroxide value - Iodometric (visual) endpoint determination (ISO standard No.3960).

15. Internatioanl Organization for Standarization. (2010). Sensory analysis - General guidance for the design of test rooms (ISO standard No.8589).

16. Internatioanl Organization for Standarization. (2016). Sensory analysis. Methodology - General guidance for establishing a sensory profile (ISO standard No.13299).

17. Internatioanl Organization for Standarization. (2014). Sensory analysis - General guidelines for the selection, training and monitoring of selected assessors and expert sensory assessors (ISO standard No.8586).

18. Joint FAO/WHO Codex Alimentarius Commission. (2017). Codex Alimentarius. Standard for named vegetable oils. Codex stan 210-1999, revision 2001, 2003, 2009, 2017. Amendment 2005, 2011, 2013 and 2015.

19. Jolliffe, I.T., Cadima, J. (2016). Principal component analysis: a review and recent developments. Philosophical Transactions of The Royal Society A: Mathematical Physical and Engineering Sciences, 374(2065), art. no. 20150202.

https://doi.org/10.1098/rsta.2015.0202

20. Maire, M., Rega, B., Cuvelier, M.E., Soto, P., Giampaoli, P. (2013). Lipid oxidation in baked products: impact of formula and process on the generation of volatile compounds. Food Chemistry, 141(4), 3510-3518.

https://doi.org/10.1016/j.foodchem.2013.06.039

21. Majzoobi, M., Farahnaky, A., Agah, S. (2011). Properties and shelf-life of part and full-baked flat bread (Barbari) at ambient and frozen storage. Journal of Agricultural Science and Technology, 13, 1077-1090.

22. Manzocco, L., Calligaris, S., Anese, M., Nicoli, M. (2016). Determination and prediction of shelf life of oils/fats and oil/fatbased foods. In M. Hu, \& C. Jacobsen (eds.), Oxidative Stability and Shelf Life of Foods Containing Oils and Fats. AOCS American Oil Chemists' Society, pp.133-156.

https://doi.org/10.1016/B978-1-63067-056-6.00002-1

23. Martynowicz, H., Jodkowska, A., Nowacki, D., Mazur, G. (2019). A closer look at polyunsaturated fatty acids and hypertension. Advances in Hygiene and Experimental Medicine, 73, 102-108. https://doi.org/10.5604/01.3001.0013.0645

24. Melilli, M.G., Di Stefano, V., Sciacca, F., Pagliaro, A., Bognanni, R., Scandurra, S., Virzì, V., Gentile, C., Palumbo, M. (2020). Improvement of fatty acid profile in durum wheat breads supplemented with Portulaca oleracea L. Quality traits of purslane-fortified bread. Foods, 9(6), art. no. 764.

https://doi.org/10.3390/foods9060764

25. Mikulec, A., Kowlaski, S., Makarewicz, M., Skoczylas, Ł., Tabaszewska, M. (2020). Cistus extract as a valuable component for enriching wheat bread. LWT - Food Science and Technology, 118, art. no. 108713 .

https://doi.org/10.1016/j.Iwt.2019.108713

26. Mikulec, A., Kowlaski, S., Sabat, R., Skoczylas, Ł., Tabaszewska, M., Wywrocka-Gurgul, A. (2019). Hemp flour as a valuable component for enriching physicochemical and antioxidant properties of wheat bread. LWT - Food Science and Technology, 102, 164-172.

https://doi.org/10.1016/j.Iwt.2018.12.028

27. Miranda-Ramos, K., Millán-Linares, M.C., Haros, C.M. (2020). Effect of chia as breadmaking ingredient on nutritional quality, mineral availability, and glycemic index of bread. Foods, 9(5), art. no. 663 .

https://doi.org/10.3390/foods9050663

28. Mohd Ali, N., Yeap, S.K., Ho, W.Y., Beh, B.K., Tan, S.W., Tan, S.G. (2012). The promising future of chia Salvia hispanica L. Journal of Biomedicine and Biotechnology, 2012, art. no. 171956. https://doi.org/10.1155/2012/171956

29. Oliveira, M.R., Novack, M.E., Santos, C.P., Kubota, E., Severo da Rosa, C. (2015). Evaluation of replacing wheat flour with chia flour (Salvia hispanica L.) in pasta. Semina: Ciencias Agrarias, 36(4), 2545-2553.

https://doi:10.5433/1679-0359.2015v36n4p2545

30. Osuna, M.B., Romero, A., Judis, M.A., Bértola, N.C. (2016). Enrichment of the fatty acids profile of breads replaced with functional flours blends. International Journal of Research in Engineering and Technology, 05(09), 224-232.

https://doi.org/10.15623/ijret.2016.0509036

31. Pike, O. (2001). Assessment of oxidative stability for lipids. In Current Protocols in Food Analytical Chemistry. John Wiley \& Sons, Inc., pp. D2.3.1-D2.3.5.

https://doi.org/10.1002/0471142913.fad0203s00

32. Reyes-Caudillo, E., Tecante, A., Valdivia-López, M.A. (2008). Dietary fibre content and antioxidant activity of phenolic compounds present in Mexican chia (Salvia hispanica L.) seeds. Food Chemistry, 107(2), 656-663.

https://doi.org/10.1016/j.foodchem.2007.08.062

33. Romankiewicz, D., Hassoon, W., Cacak-Pietrzak, G., Sobczyk, M., Wirkowska-Wojdyła, M., Ceglińska, A., Dziki, D. (2017). The effect of chia seeds ( Salvia hispanica L.) addition on quality and nutritional value of wheat bread. Journal of Food Quality, 2017, 1-7.

https://doi.org/10.1155/2017/7352631 
34. Sandoval-Oliveros, M., Paredes-Lopez, O. (2013). Isolation and characterization of proteins from chia seeds (Salvia hispanica L.). Journal of Agricultural and Food Chemistry, 61 (1), 193-201. https://doi.org/10.1021/jf3034978

35. Scheuer, P.M., Luccio, M., Zibetti, A.W., Miranda, M.Z., de Francisco, A. (2016). Relationship between instrumental and sensory texture profile of bread loaves made with whole-wheat flour and fat replacer. Journal of Texture Studies, 47(1), 14-23. https://doi.org/10.1111/jtxs.12155

36. Simopoulos, A. (2008). The importance of the omega-6/omega-3 fatty acid ratio in cardiovascular disease and other chronic diseases. Experimental Biology and Medicine, 233(6), 674-688. https://doi.org/10.3181/0711-MR-311

37. Smith, G., Atherton, P., Reeds, D., Mohammed, B., Rankin, D., Rennie, M., Mittendorfer, B. (2011). Dietary omega-3 fatty acid supplementation increases the rate of muscle protein synthesis in older adults: a randomized controlled trial. American Journal of Clinical Nutrition, 93(2), 402-412.

https://doi.org/10.3945/ajcn.110.005611

38. Stone, H., Sidel. J.L. (2004). Sensory Evaluation Practices (3rd ed). Redwood City: Academic Press Inc., pp. 87-90. https://doi.org/10.1016/B978-012672690-9/50002-0

39. Szczesniak, A.S. (2002). Texture is a sensory property. Food Quality and Preference, 13(4), 215-225.

https://doi.org/10.1016/S0950-3293(01)00039-8
40. Ulbricht, T.L.V., Southgate, D.A.T. (1991). Coronary heart disease: seven dietary factors. Lancet, 338(8773), 985-992. https://doi.org/10.1016/0140-6736(91)91846-M

41. Vázquez-Ovando, A., Rosado-Rubio, J.G., Chel-Guerrero, L.A., Betancur-Ancona, A. (2010). Dry processing of chía (Salvia hispanica L.) flour: chemical characterization of fiber and protein. CyTA - Journal of Food, 8(2), 117-127. https://doi.org/10.1080/19476330903223580

42. Vuksan, V., Jenkins, A., Brissette, C., Choleva, L., Jovanovski, E., Gibbs, A., Bazinet, R.P., Au-Yeung, F., Zurbau, A., Ho, H.V., Duvnjak, L., Sievenpiper, J.L., Josse, R.G., Hanna, A. (2017). Salba-chia (Salvia hispanica L.) in the treatment of overweight and obese patients with type 2 diabetes: A double-blind randomized controlled trial. Nutrition, Metabolism, and Cardiovascular Diseases, 27(2), 138-146.

https://doi.org/10.1016/j.numecd.2016.11.124

43. Zettel, V., Hitzmann, B. (2018). Applications of chia (Salvia hispanica L.) in food products. Trends in Food Science \& Technology, 80, 43-50.

https://doi.org/10.1016/j.tifs.2018.07.011

Submitted: 10 July 2020. Revised: 3 September and 12 October 2020. Accepted: 28 October 2020. Published on-line: 9 December 2020 . 